\title{
Human Rights at Sea and the Law of the Sea
}

\author{
Tafsir Malick Ndiaye* \\ Judge of the International Tribunal for the Law of the Sea Am Int' Seegerichtshof 1, Hamburg, Germany \\ Email: ndiaye@itlos.org
}

How to cite this paper: Ndiaye, T. M. (2019). Human Rights at Sea and the Law of the Sea. Beijing Law Review, 10, 261-277. https://doi.org/10.4236/blr.2019.102016

Received: December 20, 2018

Accepted: March 22, 2019

Published: March 25, 2019

Copyright $\odot 2019$ by author(s) and Scientific Research Publishing Inc. This work is licensed under the Creative Commons Attribution International License (CC BY 4.0).

http://creativecommons.org/licenses/by/4.0/

\begin{abstract}
We must note that it is through the principle of inter-State sharing that the law of the sea was instituted, making individual interests eventually laid to rest. That is to say, individuals are deprived of locus Standi because only on behalf of States can a matter be brought before the International Tribunal for the Law of the Sea. However, International Courts and Tribunal called to settle disputes under UNCLOS are bound by article 293 of the Convention under which the law applicably consists of the said Convention and other rules of international law not incompatible with it.
\end{abstract}

\section{Keywords}

Human Rights, Sea, Law of the Sea, Duty to Render Assistance, Inspecting and Flag States

\section{Introduction}

Ever since that "wood joinery" called throne was created and men sit on it, man began wandering. In other words, the individual is in a perpetual exile within the community of States. It is through a principle of inter States sharing that the law of the sea was instituted, making individual interest eventually laid to rest.

The Third United Nations Conference on the Law of the Sea, the subject of which was the national appropriation of maritime areas between different cate-

*TM NDIAYE, "Les droits de l'Homme et la Mer", Colloqueannuel de la Fondation René CASSIN (Institut International des Droits de l'Homme), Faculté de droit, Université du Mans, 24-25 mai 2018; I Papanicolopulu, "Human rights and the Law of the sea" IMLI, the Law of the Sea (Vol.1), Oxford University Press, 2014, pp. 509-532; B.H Oxman, "The Rule of Law and the United Nations Convention on the Law of the Sea", 1996, 7 EJIL 353; T. TREVES, Human rights and the Law of the Sea, Berkeley Journal of international Law, vol. 28, Issue 1, 2010, pp. 1-14, Budislav VUKAS, Droit de la Mer et Droits de l'Homme, the Law of the Sea, Selected Writings) 2001, Martinus NIJHOFF Publishers, pp. 71-79. Tulio SCOVAGGI "Human Rights and immigration at Sea" in Human Rights and Immigration, Ed. By ruth RUBIO-MARIN, Oxford University Press, 2014, Chap.6, pp. 212-260. 
gories of States, brought together all States of the world, and indeed, witnessed unprecedented talks. Debates were more about spaces than principles. States take part in it, but only to conceal their interests or to justify their appropriations (Dupuy, 2016).

As stated by an author "the problem with UNCLOS and other laws of the sea instruments is that they are designed for States and not for individuals. The law of the sea is a State-centred regime, in which States that have the rights (and obligations) while people may at most be considered as beneficiaries" (Papanicolopulu, 2012).

Traditionally, even when it has had at heart human concerns, the law of the sea has spoken the language of States duties and not of individual rights" ". That is to say, individuals are deprived of Locus Standi because only on behalf of States can a matter be brought before ITLOS. However, The Seabed Dispute Settlement Chamber is opened to individuals, providing specific conditions. Legal instruments relating to the sea have a different goal, even if human rights considerations are set in their legal frame.

The Oceans and the human activities therein produce a frenetic interactivity, which reveals the harsh and dangerous nature of the marine environment. Events such as, the growing number of ship arrests, thousands of dead bodies in the Mediterranean Sea, the sinking of cruise ships, working conditions on board fishing vessels in the New Zealand and Thailand EEZ, IUU fishing, threats on fish stocks of the world, modern piracy, etc., remind us of the cold reality.

This stresses the need to protect the human rights at sea and to determine whether individuals can exercise their rights and whether States have the obligation to protect them. To this end, a combined approach of the law of the sea and the human rights appears to be necessary.

A review of the human rights ${ }^{2}$ has to be done to understand how they interact with the law of the sea, in order to draw out the possible solutions offered to the individual, considering the diptych rights of the individual and the obligations of States. Because the human rights are, a priori, applicable to any individual at sea without discrimination, be it a sailor, a pirate, a migrant, fishermen, or a simple passenger.

To achieve this, the Courts and Tribunals, instituted by legal instruments of the law of the sea reveal themselves to be of a significant breakthrough because they apply the rules in light of their goal. When examining a dispute in law of the sea, these Courts and Tribunals are very similar to Courts specialised in human rights because they apply, not only the provisions of UNCLOS but also other rules of international law that are in accordance with Article 293 of the Convention.

An adjudicating body entrusted with the task of settling disputes concerning ${ }^{1}$ I. PAPANICOLOPULU, op. cit. (note 1) p. 510.

${ }^{2}$ See TM NDIAYE, “les Droits de l'hommeaujourd'hui” in Contemporary Developments in International Law, Essays in honour of Budislav VUKAS, BRILL/NIJHOFF, 2016, Chap. 31, pp. 574-582. 
the interpretation, and application of a particular Convention cannot do so by considering that Convention is isolation. The courts and tribunals called to settle disputes under the Law of the sea convention are bound by article 293 of the Convention ${ }^{3}$, under which the law applicable to them consists of the Convention "and other rules of international law not incompatible" with it.

We will recall a few cases examined by ITLOS as illustration (II), after having looked through the human rights (I), before assessing the implementation (III).

\section{The Human Rights and the Law of the Sea}

\section{1) The international charter of the human rights}

Human rights ${ }^{4}$ are like a relic of the past to be restored, requiring the lawmaker to act as an archaeologist and even sometimes as an architect because the matter is in need of rules.

There are two opposing concepts of the international human rights; the universalist principles versus the nationalist ones, hence, creating the dialectic of solidarity and identity, which makes domestic and international legal orders synchronous in this matter.

It must, however, be noted, that the universal nature is now consecrated. A quick glance at the fundamental charters of States is enough to prove the fact, let alone the consecration of conventional or other legal instruments.

The legal apparatus is indeed impressive since we note several dozens of ${ }^{3}$ See T Treves, Human Rights and the Law of the Sea, 28 Berkeley J. International Law 1 (2010), p. 2. ${ }^{4}$ Studies on Human rights are no longer counted. We will just recall a few: F. Errnacora, "Human. Rights and Domestic Jurisdiction", Recueil des Cours de L'Académie de Droit international de La Haye (RCADI), 1968-1, V01.124, pp. 371-452; K. Vasak, "Le droit international des droits de l'homme", RCADI, 1974-w, Vol. 140, pp. 333-416; P Sieghart, The International Law of Human Rights, Clarendon Press, Oxford, 1983, 569 p.; N. Valticos, "La notion de droits de l'homme en droit international", Mélanges Virally, 1991, pp. 483-491; PL Alston (ed.), The United Nations and Human Rights. A Critical Appraisal, OUP, Oxford, 199z, 748 p.; SFDI, Colloque de Strasbourg, La protection des droits de l'homme et l'évolution du droit international, Pédone, Paris, 1998, 344 p.; T.M. Ndiaye, "Introduction aux droits de l'homme", Revue Pax Africa, Dakar, n¹, juin-août 1989, p. 8 et s.; J.S. Watson, Theory and Reality in the International Protection of Human Rights, Transnational Publishers, New-York,1999, 325 p.; Ch. Tomuschat, Human Rights: Between Realism and Idealisation, OUP Oxford, 2003, 333 p.; O. De Frouville, L'intangibilité des droits de l'homme en droit international, Pédone, Paris, 2004, 561 p.; E. Decaux (dir.), Les Nations Unies et les droits de l'homme, Pédone, Paris, 2006, 348 p.; SFDI. Colloque de Nanterre, La responsabilité de protéger, Pédone, Paris, 2oo8, 358 p.; R. Cassin, "La Déclaration Universelle et la mise en oeuvre des droits de l'homme", RCADI, 1991-n, Vol. 79, pp. 237-367; Ghandhi, "The Universal Declaration of Human Rights at fifty years", German Yearbook of International Law, 1998, pp. 206-251; M. Nowak, UN Covenant on Civil and Political Rights, CCPR Comrnentary, Engel, Kehl, 1974, p. 936; M. Sepulveda, The Nature of the Obligations under the International Covenant on Economic, Socia and Cultural Rights, Intersentia, Antwerp, 2003, 446 p.; J. Dhommeaux, "Les méthodes du Comité des droits de l'homme dans l'examen des rapports soumis par les Etats parties au Pacte sur les droits civils et politiques", Annuaire français de Droit international, 1988, pp. 331-364; R. Sodini, Le Comitédes droits économiques, sociaux et culturels, Montchrestien, Paris, 2000, 220 p. IL Vasak, la Convention européenne des droits de l'homme, LGDJ, Paris, 1964, 327 p.; Gros-Espiell, "La Convention américaine et la Convention européenne des droits de l'homme: Analyse comparative", RCADI, 1989-VII, Vol. 218, pp. 167-4r,; F. Ouguergouz, La Charte africaine des droits de l'homme et des peuples, PUF, Paris, 1993, 477 p.; K. Mbaye, Les droits de l'homme en Afrique, Pédone, Paris, 1992, $312 \mathrm{p}$. 
texts $^{5}$. The foundation of this normative instrument is the dignity of man.

The first universal declaration of all human rights is the Charter of the United Nations. Until then, human rights were of a purely national character and international initiatives were, to say the least, partial and subsidiary in a relational world marked by omnipresent sovereignty, allergic to any outside interference.

The world had to wait for the Second World War and Hitler's regime to commit such evil atrocities to see a dismantled international community ${ }^{6}$ decide to regulate the issue of the human rights. And from the beginning, the United Nations Charter has established an intimate link between human rights and peace.

Articles 1, 3, 55 and 68 of the Charter are those relating to human rights ${ }^{7}$. The Charter of the United Nations, thus, constitutes a considerable element in the human rights normative order. However, conceptual uncertainty lies in its provisions.

In fact, the concept of cooperation ${ }^{8}$ less restricts the sovereignty of States than that of action ${ }^{9}$, which infers international initiatives designed to protect human rights. These initiatives may come from State Chancelleries or from non-governmental organizations. However, the growing awareness of public opinion in the world due to the rapid development of the media has emerged as a factor contributing to the development of the cause of human rights.

Just think of the internet and its social networks [Facebook; Twitter, etc.] and all the applications, likely to change the human rights order.

We live, in fact, at a time when men have access to information as it unfolds; meaning that, what happens in one country is instantly known and revealed elsewhere so that it rapidly establishes what could be called an international human rights network.

${ }^{5}$ See I. Brownlie, Basic Documents on Human Rights, Clarendon Press, Oxford, 1992, 603 p. Office of the United Nations High Commissioner for Human Rights, Human Rights: Droits de l'homme: Recueild' instruments internationaux, Vol. 1: Instruments Universels, 2 tomes, New York/Genève, 2002, 1090 p.; Vol. II: Regional instruments, 1997, 484 p.; P.R. Ghandhi, Blackstone's International Human Rights Documents, OUP, Oxford, 2004, 507 p.; O. de Schutter et al., Code de droit International des droits de l'homme, Bruylant, Brussels, 2005, 851 p.; R Rolland and P. Tavernier, La Protection Internationale des Droits de l'Homme, “Que sais-je?”, No. 2461, PUF, Paris, 1994,128 p. ${ }^{6}$ The Preamble of the United Nations Charter reads: "Whereas the peoples of the United Nations have in the Charter reaffirmed their faith in fundamental human rights, in the dignity and worth of the human person and in the equal rights of men and women and have determined to promote social progress and better standards of life in larger freedom".

${ }^{7}$ Article 1 paragraph 3 provides: "To achieve international co-operation in solving international problems of an economic, social, cultural, or humanitarian character, and in promoting and encouraging respect for human rights and for fundamental freedoms for all without distinction as to race, sex, language, or religion". As for economic and international social cooperation, article 55(c) enounces: "the universal respect for, and observance of, human rights and fundamental freedoms for all without distinction as to race, sex, language, or religion". Article 56 reads: "All Members pledge themselves to take joint and separate action in co-operation with the Organization for the achievement of the purposes set forth in Article 55". As for the procedure, article 68 provides: "The Economic and Social Council shall set up commissions in economic and social fields and for the promotion of human rights, and such other commissions as may be required for the performance of its functions".

${ }^{8}$ Article 1, paragraph 3, op.cit. (note 4).

${ }^{9}$ Article 56, op. cit. (Note 4 ). 
However, this movement is not favoured by States that regard this as an infringement on their sovereignty. They know that they have exclusive power of action over their citizens by virtue of their personal and territorial jurisdiction, and are often the first to extol the merits of their domestic law relating to human rights. This is why States are reluctant-whether they admit it or not-in the face of external interventions in the field of human rights, whether they come from "significant gestures" of chancelleries, the international community or non-governmental organizations. Generally, States are often recalcitrant to the undifferentiated international protection system or more easily tolerate mechanisms distinguishing nationals and foreign residents.

International conventions eventually established a real international human rights system even if controlled by States. Did not Paul Valery warn us at the end of the Second World War "The era of the end of the world is beginning? (Valéry, 1979)".

However, the misunderstandings of political and constitutional language have made States with very different regimes have their own conceptions of human rights, hence the list of principles.

There is thus an order of equivalence in which the human rights have evolved and the Universal Declaration of Human Rights of December 10, 1948, was to be adopted since the Charter of the United Nations does not define human rights.

The Universal Declaration ${ }^{10}$ is unquestionably the most famous of the United Nations legal instruments relating human rights. The project was conceived by three illustrious mentors: The French René Cassin, the American Eléonore Roosevelt and the Lebanese Charles Malek.

\section{What rights are enounced in this fundamental text?}

It can be said that the Declaration is based upon four categories of rights. First, there is the personal rights; secondly, the rights which govern the relations between men and which obey a criterion of laterality; then we have the spiritual rights and finally the material rights. They can essentially be reduced to two types of rights: civil and political rights and economic, social and cultural rights. Human rights are, first and foremost, rights, that is to say, a legally protected interest, to quote Jhering, inherent to man and intended to ensure his dignity as a human being from the State and from other men.

\section{What are the characteristics of different human rights?}

Civil and political rights are considered in law, as opposable to the State. They require, to be implemented, a non-involvement or abstention of the State. These rights were consecrated with the French Revolution of 1789. They are sometimes called attributes rights, freedom rights, or the first generation of human rights ${ }^{11}$. These rights are regarded most often as the people's rights: right to come and go, freedom of expression, etc.

\footnotetext{
${ }^{10}$ The Universal Declaration of Human Rights of 10 December 1948, A/RES 217 (III) of the General Assembly of the UN.

${ }^{11}$ In the terminology used by Prof. K. Vasak in his lectures at the $8^{\text {th }}$ Academy of International Law in the Hague in 1974, see note 1, supra.
} 
As for the economic, social and cultural rights also called the second generation of human rights, they were born with the Mexican (1910) and Bolshevik (1917) revolutions and can be appreciated as human rights not opposable to the State but subject to it, or even receivable from the State. These are the equality rights, the implementation of which requires a provision of the State. These rights are often referred to as collective rights: right to work, right to health, right to education, right to information, etc.

But human rights are not fixed concepts. Every day can bring its new human rights.

Did not Claude Bernard say that "the function creates the institution?" Also, there is the third-generation human rights or solidarity rights, rights that are both opposable to the State and subject to it and presuppose the junction of actors in the social field, for example, the right to development ${ }^{12}$, the right to peace, the right to a healthy environment which finds a constitutional basis in the Stockholm Declaration $1972^{13}$, the right to a common heritage of mankind as established by the United Nations General Assembly ${ }^{14}$; The last category of rights relates to the seabed and interstellar space.

The third generation rights have been the subject of much criticism in the doctrine ${ }^{15}$. Some claim that they deal more with aspirations than rights and also they lack specific purpose. These rights would be difficult to be implemented and could even weaken human rights.

These criticisms seem to us unfounded. Human rights must become more and more flexible. In other words, the mutability of human rights must go in the direction of their amplification.

Moreover, rights were first aspirations before becoming rights. As to the impossibility of judicial implementation, it proceeds from a theoretical error consisting in basing the existence of the norm on the sanction. It is this conceptual movement that has denied the existence of constitutional law and international law.

\footnotetext{
${ }^{12}$ See K. Mbaye, "Le droit au développement", Revue des droits de l'homme, Strasbourg, 1971, pp. $5-34$.

${ }^{13}$ See T. M. Ndiaye, "La responsabilité internationale des Etats pour dommages au milieu marin", in International Law: New Actors, New Concepts Continuing Dilemmas, Liber Arnicorurn B. Bakotic, Martinus Nijhoff Publishers, Leiden, Boston, pp. 265-279. Indeed, the 1972 United Nations Conference on the Environment held in Stockholm, 1972, had to reiterate the rule. Principle 21 of the Stockholm Declaration reads "States have, in accordance with the Charter of the United Nations and the principles of international law, the sovereign right to exploit their own resources pursuant to their own environmental policies, and the responsibility to ensure that activities within their jurisdiction or control do not cause damage to the environment of other States or of areas beyond the limits of national jurisdiction". The same principle will be proclaimed by the Rio Declaration on the Environment and Development, adopted on 13 June 1992 (A/CONF/51/2.6.Rev.1 of 14 June 1992). In its 8 July 1996 advisory opinion related to the lawfulness of the threat or use of nuclear weapons, the International Court of Justice confirms the binding force of the principle: ICJ Reports p. 226, spec. pp. 241-242, paragraph 29. See also the case concerning the Gabeilcovo-Nagymaros Project (Hungary/Slovakia), judgment of 25 September 1997, ICJ, reports 1997 p.7 spéc. P. 41, paragraph 53. ${ }^{14} 1969$ United Nations General Assembly 2749 (XXIV) Resolution.

${ }^{15}$ See R. Pelloux "Vrais et faux droits de l'homme: Problèmes de définition et de classification", Revue du droit public et de la science politique en France et à l'étranger, 1981, p. 53.
} 
The truth is that the sanction is not a prerequisite to the existence of the norm. It only affects its execution. It is not because the people from Dakar do not take the zebra crossing that it does not exist.

Another argument raised against the so-called solidarity rights relates to its prioritisation. In this regard, the indivisibility of human rights and the lack of priority in law should be emphasized. It is only logically that a certain precedence can be conceived because certain human rights-the right to life, for instance-are rights without which the title to the complaint becomes soluble.

Today we have this category of human rights called the rights of humanity, symbolized by the establishment of the International Criminal Court created by the Rome Statute. Indeed, the Rome Conference, on 17 July 1998 resulted in the adoption of the Convention on the Statute of the International Criminal Court. This new permanent criminal Court is competent to repress individuals accused of internationally qualified and imprescriptibly crimes: crime of genocide; crimes against humanity; war crimes and the crime of aggression ${ }^{16}$. The Court had predecessors that were of a one off nature in that they were ad'hoc tribunals, whether they are the Nuremberg and Tokyo Courts, established by the victorious powers of the Second World War or the Special Tribunals established by the Security Council for crimes committed in the former Yugoslavia, Rwanda, Cambodia, Sierra Leone or Lebanon.

The States Parties to the Rome Statute are Conscious that all peoples are united by common bonds, their cultures are pieced together in a shared heritage, and concerned that this delicate mosaic may be shattered at any time. In the course of this century, thousands of children, women and men have been the victims of atrocities that are beyond imagination and this has deeply shocked human consciousness ${ }^{17}$. States are determined to put an end to the impunity of the perpetrators of these crimes and to work for the prevention of new crimes. To this end, they have established the International Criminal Court, which they recognize as "complementary to national criminal Courts ${ }^{18}$."

As one author remarks (Sur, 1999), individuals become direct subjects of the obligations imposed, in the sense that they can be directly brought before an international Court, by an internationally diligent action, thus, eluding entirely their national Courts. This is a significant difference from previous institutional developments, which for example had the Security Council ask a State, Libya, to hand over some of its nationals to other States to face justice, an obligation which goes beyond the cooperation established by the conventions relating to

\footnotetext{
${ }^{16}$ Article 5 of the Rome Statute states in its first paragraph: "The jurisdiction of the Court shall be limited to the most serious crimes of concern to the international community as a whole. The Court has jurisdiction in accordance with this Statute with respect to the following crimes: (a) The crime of genocide; (b) Crimes against humanity; (c) War crimes; (d) The crime of aggression". See document A/CONEa83/9 of 7 July 1998 and amended by the minutes of 10 November 1998, 11 July 1999, 30 November 1999, 8 May 2000, 17 January 2001 and 16 January 2002: The Statute entered into force in force on 1. July 2002.

${ }^{17}$ Preamble of the Rome Statute.

${ }^{18}$ Ibid.
} 
the suppression of air piracy ${ }^{19}$.

Individuals are, however, rather objects than subjects of the norms, since they cannot themselves initiate proceedings, which remain the preserve of States Parties, the Security Council or the Prosecutor under the control of a Pre-Trial Chamber.

\section{What are the norms relating to human rights?}

The universal value of human rights justifies the adoption of legal instruments designed to define the various rights and to enable States to commit to them. The specificities resulting from East-West sharing and independence lead to a regionalization of the promotion and protection of human rights. This is why regional instruments must be distinguished.

At the universal level, there is the International Charter of Human Rights composed of the Universal Declaration of Human Rights of $1948^{20}$ and the two 1966 Covenants adopted within the United Nations relating to civil and political rights on the one hand and the economic, social and cultural rights, on the other.

At the regional level, mention should be made of the European Convention for the Protection of Human Rights signed at Rome on 4 November 1950 and supplemented by five additional Protocols; the American Convention on Human Rights signed in San José, Costa Rica on November 22, 1959, and finally the African Charter on Human and Peoples' Rights, which was elaborated under the auspices of the OAU and was adopted by acclaim on 28 June 1981 by the Conference of Heads of State and Government in Nairobi, Kenya. The African Charter entered into force on 21 October 1986.

Besides the prolific sources of human rights written norms and standards (resolutions, declarations and conventions), not all have the same legal power, it is necessary to highlight the dedication of the customary law in the various human rights instruments which is a fundamental aspect of the rights of individuals.

The jurisprudence of the International Court of Justice and that of the International Tribunal for the Law of the Sea sufficiently demonstrate this ${ }^{21}$. As we can see, the rules relating to human rights are of various origins. They are of unequal legal force and differ in their areas of application and scope. They are also different in terms of their beneficiaries and recipients.

Moving on from the legal thought to the implementation, we see that the problems remain stubborn. Human rights are indeed the subject of "practical work" to say the least. There are a number of factors hampering the develop-

\footnotetext{
${ }^{19}$ Resolution 731 of January, 21 1992; Res. 748 of March 31, 1992.

${ }^{20}$ Op. Cit. (note 8 ).

${ }^{21}$ See the Corfu Channel case (1949); Case of the crime of genocide (195o); Case of Barcelona Traction (197o, $₫ 33$ and 34); Case of Namibia (1971, $\$ 131$ ); The case of the American hostages in Tehran (1980, \$91); Lagrand case (1999); Avena case and other Mexican nationals (2004). For the International Tribunal for the Law of the Sea, see 9 Prompt Release Cases and the Louisa Case (2013). See R Vukas, "Droit de la mer et droits de l'homme", in the Law of the Sea Selected Writings, MartinusNijhoff Publishers, 2004, pp. 71-79.
} 
ment of human rights.

First, the totalitarian nature of many political regimes. These shameful dictators, who feed on blood and silence, and of which our Continent provides despicable examples.

Second, economic underdevelopment and corrupt leaders who limit certain of the second generation rights: right to work, to health, to education.

Then, the diversity of civilizations and cultural contexts that tends to question the universal character of human rights in a "finite world" (Valéry), by creating modes of allegiance removed from Sate control.

Finally, there is the international structure with "its cornerstone that seems to resist time (Virally, 1977)" and which is called sovereignty and its corollary: the principle of non-interference in the internal affairs of a State ${ }^{22}$.

These factors make it impossible to control the enforcement of States obligations. This is why the struggle for the protection of human rights is elaborating new practices. And violations of human rights provoke the reaction of States-individual or collective actions; expression of disapproval; significant gestures; suspension of assistance, etc., from international organizations: commissions of inquiry, reports, etc., and/or non-governmental organizations. The latter appear to be the most effective in the human rights order insofar as their actions are multiple and multifaceted and they can dissuade the most powerful State $^{23}$.

This mobilization of shame often appears salutary in the case of violations of human rights. It is to be hoped that citizens in different countries in the world will make practice of exercising their legal capacity, thus, breaking the wall of silence, in case of violation of their rights to advance the perpetual quest for human dignity, which is the inter, trans and sub-national movement for human rights. Then human rights can move from being a "thing" to being a "machine".

\section{2) LAW OF THE SEA}

The law of the sea deals with the protection of human rights only as incidental questions because of the lack of Locus standi for the individual, given that only States can refer to ITLOS. The seabed chamber is opened to individuals with respect to the activities in the Area.

UNCLOS is not a human rights legal instrument as such, and does not directly give rights to individuals. Nevertheless, human rights considerations are set in its normative infrastructure. It obliges the States to protect and respect the specific rights in certain cases.

It provides in its article 98 to render assistance to "any person found at sea in danger of being lost; to rescue persons in distress, or to other ship, its crew and its passengers and, where possible"24. This is a traditional obligation in the marine environments. This provision provides as well that:

"shall promote the establishment, operation and maintenance of an ade-

\footnotetext{
${ }^{22}$ Article 2 paragraph 7 of the United Nations Charter.

${ }^{23}$ Just think of Amnesty International or Human Rights Watch.

${ }^{24}$ Article 98 of UNCLOS.
} 
quate and effective search and rescue service regarding safety on and over the sea and, where circumstances so require, by way of mutual regional arrangements cooperate with neighbouring States for this purpose".

With respect to activities in the Area, necessary measures shall be taken to ensure effective protection of human life ${ }^{25}$.

Moreover, State penalties for violations of fisheries laws and regulations in the exclusive economic zone may not include imprisonment, in the absence of agreements to the contrary by the States concerned, or any other form of corporal punishment. ${ }^{26}$

In cases of arrest or detention of foreign vessels the coastal State shall promptly notify the flag State, through appropriate channels, of the action taken and of any penalties subsequently imposed. ${ }^{27}$

Monetary penalties only may be imposed with respect to violations of national laws and regulations or applicable international rules and standards for the prevention, reduction and control of pollution of the marine environment, committed by foreign vessels beyond the territorial sea. ${ }^{28}$

All States, enjoy the right of innocent passage but only in case of distress or for the purpose of rendering assistance to persons, ships or aircraft in danger or distress ${ }^{29}$.

The Agreement on straddling Fish stock provides that States shall comply with all such laws and regulations and all generally accepted international regulations relating to the prevention of collisions at sea. ${ }^{30}$

These provisions enable the safeguarding of the freedom of navigation of the crew and the protection of the interests of the navigation and the shipowners, that is to say the course of the economic activities.

The flag State can, if needs be, resort to the prompt release procedure, which is an expeditious procedure for the prompt release of the vessel or its crew upon

\footnotetext{
${ }^{25}$ Article 146 of UNCLOS, states: "With respect to activities in the Area, necessary measures shall be taken to ensure effective protection of human life. To this end the Authority shall adopt appropriate rules, regulations and procedures to supplement existing international law as embodied in relevant treaties".

${ }^{26}$ Article 73, paragraph 3 of UNCLOS States "Coastal State penalties for violations of fisheries laws and regulations in the exclusive economic zone may not include imprisonment, in the absence of agreements to the contrary by the States concerned, or any other form of corporal punishment".

${ }^{27}$ Article 73, paragraph 4 of UNCLOS states "In cases of arrest or detention of foreign vessels the coastal State shall promptly notify the flag State, through appropriate channels, of the action taken and of any penalties subsequently imposed."

${ }^{28}$ Article 230 of UNCLOS.

${ }^{29}$ Article 18, paragraph 2 of UNCLOS states: "Passage shall be continuous and expeditious. However, passage includes stopping and anchoring, but only in so far as the same are incidental o ordinary navigation or are rendered necessary by force majeure or distress or for the purpose of rendering assistance to persons, ships or aircraft in danger or distress".

${ }^{30}$ Article 21, paragraph 10 of the Agreement of UNFCA States: "The inspecting State shall require its inspectors to observe generally accepted international regulations, procedures and practices relating to the safety of the vessel and the crew, minimize interference with fishing operations and, to the extent practicable, avoid action which would adversely affect the quality of the catch on board. The inspecting State shall ensure that boarding and inspection is not conducted in a manner that would constitute harassment of any fishing vessel".
} 
the posting of a reasonable bond or other financial security. To this day, nine prompt release cases have been examined by ITLOS. We shall go through some cases.

\section{Case Law}

\section{1) SAIGA}

The M/V SAIGA is an oil tanker flying the flag of Saint-Vincent-and-theGrenadines. Its character at the relevant time was Lemania Shipping Group Limited, registered in Geneva, Switzerland. At the time of the incident with respect to which the proceedings were instituted, the M/V SAIGA served as a bunkering vessel supplying fuel oil to fishing vessels and other vessels operating off the coast of Guinea.

In the early morning of 27 October 1997, the M/V SAIGA having crossed the maritime boundary between Guinea and Guinea Bissau, entered the exclusive economic zone of Guinea approximately 32 nautical miles from the Guinean island of Alcatraz. The same day, it supplied gas oil to three fishing vessels, the Guiseppe Primo, the Kriti and the Eleni S. On 28 October 1997, the M/V SAIGA was arrested by Guinean Customs Patrol Boats. In the course of action, at least two crew members were injured. On the same day the vessel was brought to Conakry, Guinea, where the vessel and its crew were detained. Subsequently, two injured crew members were allowed to leave and the cargo was discharged in Conakry upon the orders of local authorities. Saint-Vincent-and-the-Grenadines instituted the proceedings under article 292 of the Law of the Sea Convention. In the SAIGA case, Guinea places the responsibility for any damage resulting from the use of force on the Master and crew of the ship ${ }^{31}$.

Examining the use of force of Guinea during the arrest of the SAIGA, ITLOS must take into account the circumstances of the arrest in light of the applicable rules of international law. Although the Convention does not contain any specific provision regarding the use of force, the applicable international law in article 293 of the Convention requires that the use of force must be avoided as far as possible and, where force is inevitable, it must not go beyond what is reasonable and necessary in the circumstances.

In the view of the Tribunal, considerations of humanity must apply in the law of the sea, as they do in other areas of international law.

In the same vein, the UN Fish Stocks Agreement concludes Article 22(1)(f $)^{32}$ by recalling the use of force principle during ship arrests at sea ${ }^{33}$.

${ }^{31}$ The MV "SAIGA" Case (St Vincent and the Grenadines V. Guinea) list of case: $\mathrm{N}^{\circ} 1$, Judgment of $1^{\text {st }}$ July 1999.

${ }^{32}$ See article 22 of the UN Fish Stocks Agreement dealing with the basic procedures for boarding and inspection pursuant to article 21. It establishes the rights and duties of the Inspecting State, the Flag State and actions to be taken in conflicting circumstances concerning the master of a vessel as well as international regulations.

${ }^{33}$ Article 22 (f) the UN Fish Stocks Agreement states that inspecting States shall "avoid the use of force except when and to the degree necessary to ensure the safety of the inspectors and where the inspectors are obstructed in the execution of their duties. The degree of force used shall not exceed that reasonably required in the circumstances". 


\section{2) CAMUCO CASE}

The CAMOUCO is a fishing vessel flying the flag of Panama. Its owner is "Merco-Pesca" (SA) a company registered in Panama. On 16 September 1999, the CAMOUCO left the port of Walvis Bay (Namibia) to engage in longline fishing in the Southern seas. Its master was a Spanish national. On 28 September, the CAMOUCO was boarded by the French surveillance frigate Floréal in the economic exclusive zone of the Crozet Islands (French Colony), 160 nautical miles from the northern boundary of the zone. The procés-verbal of violation stated that six tonnes of frozen toothfish were found in the holds of the CAMOUCO and that the Master was in breach of law on account of: Unlawful fishing in the EEZ of the Crozet Islands, under the French jurisdiction; attempted flight to avoid verification by maritime authority; etc.

In the CAMUCO CASE, the vessel being in detention was not disputed. However, the parties were in disagreement whether the Master of the vessel was also in detention. It is admitted that the Master was under "Court supervision", that his passport has also been taken away from him by the French authorities, and that, consequently, he is not in a position to leave Réunion; the so-called "Controlejudiciaire" in the French system.

The Tribunal considers that, in the circumstances of this case, it is appropriate to order the release of the Master in accordance with article 292, paragraph 1, of the Convention. ${ }^{34}$

\section{3) MONTE CONFURCO}

In the MONTE CONFURCO case as well, the parties did not agree as to whether the Master was under arrest, because placed under "court supervision" by the French authorities, and his passport was taken away from him, according to article 292 of the convention.

In the view of the Tribunal, being under "court supervision" is simply another form of detention ${ }^{35}$.

The issue of the detention of the Master and its crew also arose in the JUNO TRADER case (ST Vincent and the Grenadines V. Guinea) and the HOSHINMARU case (Japan v. Russian Federation), respectively ${ }^{36}$.

\section{4) JUNO TRADER}

\footnotetext{
${ }^{34}$ Article 292, paragraph 1, of the Convention states: "Where the authorities of a State Party have detained a vessel flying the flag of another State Party and it is alleged that the detaining State has not complied with the provisions of this Convention for the prompt release of the vessel or its crew upon the posting of a reasonable bond or other financial security, the question of release from detention may be submitted to any court or tribunal agreed upon by the parties or, failing such agreement within 10 days from the time of detention, to a court or tribunal accepted by the detaining State under article 287 or to the International Tribunal for the Law of the Sea, unless the parties otherwise agree".

${ }^{35}$ See the MONTE CONFURCO case (Seychelles v. France) Prompt release, case $\mathrm{N}^{\circ} 6$, judgment, ITLOS reports 2000, p.86 paragraph 90; CAMOUCO case (panama v. France) Prompt release, case $\mathrm{N}^{\circ} 5$, ITLOS, Reports 2000 , p. 10 paragraph 71.

${ }^{36}$ See the JUNO TRADER case (ST Vincent and the Grenadines V. Guinea) prompt release, judgment of 18 December 2004, case $\mathrm{N}^{\circ} 13$; the HOSHINMARU case (Japan v. Russian Federation), prompt release, case $\mathrm{N}^{\circ} 14$, judgment of 6 August 2007.
} 
In the JUNO TRADER case $^{37}$ the parties were in disagreement whether the crew was detained. According to the Applicant, while some passports have been returned, as of 7 December 2004 the passports of six crew members have not been returned. The Respondent contended that Guinea-Bissau did not detain any crew members of the JUNO TRADER and returned passports on request. In a letter dated 15 December 2004, received during the Tribunal's deliberations, the Respondent informed the Tribunal that "the Guinea-Bissau authorities (FISCAP) have already delivered the remaining passports and all members of the crew can freely leave Guinea-Bissau". The letter added that "the remaining passports have already been delivered without any formal conditions (such as posting of a bond) and are free to leave Guinea Bissau". On 16 December 2004, the Applicant, whilst confirming the information regarding delivery of passports, did not withdraw its request for an order from the Tribunal concerning the release of the members of the crew.

In this respect, the Tribunal notes that the members of the crew are still in Guinea-Bissau and subject to its jurisdiction. The Tribunal places on record the undertaking given by the Respondent in its letter dated 15 December 2004 and 26 declares that all members of the crew should be free to leave Guinea-Bissau without any conditions.

\section{5) HOSHINMARU}

In the HOSHINMARU case $^{38}$ the Tribunal notes the statement by the Respondent that the restrictions on the free movement of the Master were lifted on 16 July 2007. The Tribunal further notes that the Master and the crew still remain in the Russian Federation.

For these reasons and in view of the circumstances of the case, the Tribunal finds that the Respondent has not complied with article 73, paragraph 2, of the Convention, that the Application is well-founded, and that, consequently, the Russian Federation must release promptly the HOSHINMARU, including the catch on board and its crew in accordance with paragraph $102^{39}$.

The Tribunal decided that the Russian Federation must proceed into a prompt release of the HOSHINMARU, the master and the crew without further delay upon the posting of a reasonable bond or other security determined by the tribunal.

\section{6) TOMINMARU}

In the TOMINMARU case ${ }^{40}$ (Japan vs. Russian Federation, 2007), it must be recalled the observations of the Tribunal relating to the confiscation and the international standards of due process.

\footnotetext{
${ }^{37}$ See the JUNO TRADER case (ST Vincent and the Grenadines V. Guinea) prompt release, judgment of 18 December 2004, case $\mathrm{N}^{\circ} 13$.

${ }^{38}$ See the HOSHINMARU case (Japan v. Russian Federation), prompt release, case $\mathrm{N}^{\circ} 14$, judgment of 6 August 2007.

${ }^{39}$ Article 73, paragraph 2, of the Convention states that: "Arrested vessels and their crews shall be promptly released upon the posting of reasonable bond or other security."

${ }^{40}$ See the TOMINMARU case (Japan v. Russian Federation), prompt release, case $\mathrm{N}^{\circ} 15$, judgment of 6 August 2007.
} 
As already declared by the tribunal in MONTE CONFURCO case judgment ${ }^{41}$, article 73 identifies two interests, the interest of the coastal State to take appropriate measures as may be necessary to ensure compliance with the laws and regulations adopted by it on the one hand and the interest of the flag State in securing prompt release of its vessels and their crews from detention on the other. It strikes a fair balance between the two interests. It provides for release of the vessel and its crew upon the posting of a bond or other security, thus protecting the interests of the flag State and of other persons affected by the detention of the vessel and its crew. The release from detention can be subject only to a "reasonable" bond.

The Tribunal stress that a judgment under article 292 of the Convention must be without prejudice to the merits of any case before the appropriate domestic forum against the vessel, its owner or its crew. And this is to be taken into account to establish a fair balance between the interests of a coastal State and those of a flag State.

It is the view of the Tribunal that confiscation of a fishing vessel must not be used in such a manner as to upset the balance of the interests of the flag State and of the coastal State as established in the Convention. A decision to confiscate eliminates the provisional character of the detention of the vessel rendering the procedure for its prompt release without object. Such a decision should not be taken in such a way as to prevent the ship owner from having recourse to available domestic judicial remedies, or as to prevent the flag State from resorting to the prompt release procedure set forth in the Convention; nor should it be taken through proceedings inconsistent with international standards of due process of law. A confiscation decided in unjustified haste would jeopardize the implementation of article 292 of the Convention.

The Tribunal notes that the decision of the Supreme Court of the Russian Federation brings to an end the procedures before the domestic courts. This has not been contested by the Applicant. After being informed of that decision, the Applicant did not maintain its argument that the confiscation of the TOMIMARU is not final. The Tribunal notes also that no inconsistency with international standards of due process of law has been argued and that no allegation has been raised that the proceedings which resulted in the confiscation were such as to frustrate the possibility of recourse to national or international remedies.

\section{7) VIRGINIA G}

Finally, in the VIRGINIA $\mathrm{G}^{42}$ case Panama argues that it "is bringing this action against Guinea Bissau within the framework of diplomatic protection" and that it "takes the cause of its national and the vessel VIRGINIA G with everything on board, and every person and entity involved or interested in her opera-

\footnotetext{
${ }^{41}$ See the MONTE CONFURCO case (Seychelles v. France) Prompt release, case $\mathrm{N}^{\circ} 6$, judgment, ITLOS reports 2000, p.208 paragraph 70 .

${ }^{42}$ See the M/V “Virginia G” case (Panama v. Guinea), case N 19, judgment of 14 April 2014.
} 
tions".

To support its position, Panama refers to the SAIGA case ${ }^{43}$ where the Tribunal states that "the Convention considers a ship as a unit, as regards the obligations of the flag State". Thus, the ship, everything on it, and every person involved or interested in its operations are treated as an entity linked to the flag State. The nationalities of these persons are not relevant. The judgment was rendered by the United Nations International Law Commission.

We will remind that Panama refers also to article 18 of the draft articles on diplomatic protection adopted by the commission in 2006 regarding the protection of ships' crews, who have on board dozens of nationalities. It States:

"The right of the State of nationality of the members of the crew of a ship to exercise diplomatic protection is not affected by the right of the State of nationality of a ship to seek redress on behalf of such crew members, irrespective of their nationality, when they have been injured in connection with an

injury to the vessel resulting from an internationally wrongful act".

On this basis, ITLOS concludes that the VIRGINIA G must be treated as an entity and that "each ship may have a crew of different nationalities".

The similarities in prompt release system lie on the arrest of vessels. It is governed by the UNCLOS article 292 stating that were the authorities of a State-Party have detained a vessel flying the flag of another State-Party and it is alleged that the detaining State has not complied with the provisions of the Convention, the question may be submitted to the International Tribunal for the Law of the Sea. The differences reside in the nature of the vessels involved in the detention: Bunkering vessels, fishing vessels or any vessel performing an unlawful act in an EEZ.

\section{Implementing Human Rights at Sea}

Moving on from legal thought to that of implementation, we see that the asperities remain stubborn. There are a number of factors caused by human activities in the seas and oceans that hamper the development of human rights.

The contemporary threats to the oceans that are the biggest challenges for States are just thought of, such as transportation and security issues; arms and drug smuggling; piracy; unregulated and illegal fishing; the question of thousands of migrants who have drowned in the Mediterranean; the question of refugees; the question of pollution; the question of boarding; etc.

The law of the sea classical approach is based on the question of jurisdiction to determine which State can exercise jurisdiction over ships found in the different maritime areas in the ocean, in accordance with international law.

Certain States believe that international human rights law does not apply to individuals found beyond the territory of the State. This is a restrictive interpre${ }^{43}(\mathrm{M} / \mathrm{V}$ “SAIGA” (No. 2) (Saint Vincent and the Grenadines v. Guinea), ITLOS Reports 1999, p. 10, at p. 48 , para. 106). 
tation of the jurisdiction, treated as part of the territory.

This conception results in numerous violations of basic human rights, such as the right not to be subjected to enforced disappearance or torture. The most cited example is the kidnapping of non-nationals suspected of terrorism by secret agents in another State with the complicity of the local intelligence services.

The kidnapped persons are then transported to third countries where they are tortured to extract information from them. In this regard, States detain these suspected terrorists outside their national territory.

It should be recalled that human rights have a conclusive effect, that is to say, they bind the States Parties irrespective of the place of commission of the secret agent's act, and the Court simply translates the power or the effective control of some agents of the State, as soon as it exercises its functions. In the law of the sea, the Court defines the competences and rights of the State in the various maritime areas where it is supposed to intervene, including in high seas for the flag state, for instance.

Accordingly, the State's "jurisdiction" is not limited to its territory; meaning that the acts of these bodies, outside the national territory, may engage the responsibility of the State because they exercise of its jurisdiction and particularly, the acts commit on board a vessel flying its flag.

These conceptions must not prevail if we want to protect the interest of the individual from the State because they may undermine the precision and predictability of human rights at sea.

As indicated by an author, certain States adopt a restrictive interpretation of the notion of jurisdiction. This appears as a tool used to elude international human rights law. The theory is that international human rights' rules do not apply to persons found outside the national territory of the state. Thus, jurisdiction is understood as territory. This theory leads to violation of a number of fundamental rights, such as the right not to be subjected to enforced disappearance $^{44}$.

It must be stated that the human rights treaties apply not only with the territory of states parties but also the obligations bind states wherever their agents ${ }^{44}$ See T. Scovazzi op. cit. (note 1) pp.248; Somme non-American nationals suspected of terrorism were kidnapped by American secrets agents in States other than the United Sates, including several European countries with the complicity of the local secret services, and were forcibly transported to a third state where torture was carried out to extract information from them. As stated In 2006 by the United States legal advisor, John Bellinger, article 3 of CAT "No State party shall expel, return or extradite a person to another State where there are substantial grounds to believe that he would be in danger of being subjected to torture" and other human rights treaties to which the United States is a party as well, are deemed not to be binding on the US agents when they act outside the national territory. Mr. Bellinger said "For more than a decade, the position of the US government, and our Courts, has been that all those terms refer to returns from, or transfers out from the United States. So we think that article 3 of the CAT is legally binding upon us with respect to transfers of anyone from the United States; but we don't think it is legally binding outside the United States" Parliamentary Assembly of the Council of Europe (PACE), Alleged Secrets detentions and Wrongful Interstates Transfers Involving Council of Europe Member States, Draft Reports-Part II (Explanatory Memorandum), Rapporteur Mr. Dick Marty, Part II, June 2006, para. 272. 
act $^{45}$.

The aspiration of maintenance of peace, justice and progress for all people of the world ${ }^{46}$ is pursued through the establishment of the rule of the law in the seas and oceans.

As the European court of Human Rights put it "the special nature of the maritime environment relied upon by government in the instant case cannot justify an area outside the law where ships crews are covered by no legal system capable of affording them enjoyment of the rights and guarantees protected by the European Convention on human rights ${ }^{47}$.

As far as the significance is concerned, the awareness is of essence in practical, social or academic aspect. The process of awareness will undoubtedly be enhanced by the interpretation and application of the rules, regulations and UNCLOS. Moreover, the dialogue between international and arbitral Tribunal will gradually establish an international regime for human rights at sea. This could lead diplomats, i.e. sovereign States to negotiate a multilateral Convention on the issue for the protection of human beings at sea.

\section{Conflicts of Interest}

The author declares no conflicts of interest regarding the publication of this paper.

\section{References}

Papanicolopulu, I. (2012). The Law of the Sea Convention: No Place for Persons? International Journal Marine and Coastal Law, 27, 867. https://doi.org/10.1163/15718085-12341256

Virally, M. (1977). Une pierre d'angle qui résiste au temps: Avatars et pérennité de l'idée de souveraineté in les relations internationales dans un monde en mutation, HE1 50, SIJTHOFF, Leiden, 179-196.

Valéry, P. (1979). Regards sur le monde actuel, collection Idées, Gallimard, Paris, 376 P, voir p. 19.

Sur, Pr. S. (1999). Vers une Cour Pénale internationale: La convention de Rome entre les ONG et le Conseil de Sécurité. Revue générale de droit internationale public, $N^{\circ} 1$, 29-45.

Dupuy, R. J. (2016). The Law of the Sea, SIJHOFF Oceana, 1974, 209 p, spec. Chap. III, 46-101. Ndiaye, T. M. Challenges and Prospects of the New Law of the Sea. State Practice \& International Law Journal (SPILJ), 3, 1-40.

\footnotetext{
${ }^{45}$ See Scovazzi, Ibid. As the author rightly pointed out, in the context of human rights treaties, the term "jurisdiction" is to be understood as "power or effective control", with the consequence that respect for human right sis due to any individual who is under the power or effective control of any agent of a State party, wherever he happens to act. The general rule that treaties have to be interpreted in good faith in accordance with the ordinary meaning of the terms of the treaty in their context and in the light of its object and purpose must always be respected. See article 31, para.1 of the Vienna Convention on the law of treaties of 29 May 1969.

${ }^{46}$ UNCLOS, Preamble.

${ }^{47}$ Medvedyev and ors. V. France, ECHR, Judgment, 29 March, para. 81.
} 